\title{
Social Representations of Children and Parents in Parliamentary-Committee Debates about the Inclusion of Child Psychological Maltreatment in the Quebec Youth Protection Act
}

\author{
Nathalie Plante *(D) and Lilian Negura (1D \\ School of Social Work, University of Ottawa, Ottawa, ON K1N 6N5, Canada; lilian.negura@uottawa.ca \\ * Correspondence: nplan065@uottawa.ca
}

\begin{abstract}
Child psychological maltreatment (CPM) was incorporated into the Quebec Youth Protection Act (YPA) in 2006. At that time, various civil-society actors were invited to present to Parliament their views on these legislative changes. The objective of this article is to document the social representations mobilized by the stakeholders in the parliamentary committee in relation to the inclusion of CPM in the Quebec YPA. After explaining our research objectives, questions, and methodology, we will discuss our results, in particular about the distinctive nature of children as a representational object. This specificity will be analyzed in order to better understand the type of communication it generates and the corresponding hegemonic representation of parents. Specifically, implications related to the representational dynamics identified are discussed in relation to our collective capacity (or incapacity) to debate sensitive issues such as child abuse.
\end{abstract}

Keywords: child psychological maltreatment; social representations; sacralized social representations; parliamentary commission; youth protection; Youth Protection Act

Citation: Plante, N.; Negura, L. Social Representations of Children and Parents in ParliamentaryCommittee Debates about the Inclusion of Child Psychological Maltreatment in the Quebec Youth Protection Act. Societies 2021, 11, 114. https://doi.org/10.3390/soc11030114

Academic Editor: Ian Kelvin Hyslop

Received: 18 August 2021

Accepted: 14 September 2021

Published: 18 September 2021

Publisher's Note: MDPI stays neutral with regard to jurisdictional claims in published maps and institutional affiliations.

\section{Introduction}

First adopted in 1977, the Quebec Youth Protection Act (YPA) addresses situations where the security or the development of a child is considered to be in danger and that potentially require the State's intervention. It is important to know that Quebec's YPA constitutes what is called an exceptional law; by its very nature and purpose, it is not meant to act upon every child and family, but only upon those in which the State's intervention is considered a necessity to protect the children. Furthermore, it gives important powers to Youth Protection Directors (YPD) in order to protect children; for instance, the power to remove a child from their home, control contact with the family of origin, enter a home for investigation without a warrant, and more. These powers are the result of a long debate in Quebec society, contrasting the freedom of families, in particular parents, with the protection of children, a tension that has marked the evolution of youth protection in Quebec since its beginning [1,2].

In essence, the principles on which the YPD intervention is based have not changed since 1977, but the grounds for compromise have been redefined, with the aim of making them more precise in order to better respect the exceptional nature of the law [3]. These grounds constitute the formal definition of child abuse in Quebec, and, in 2006, psychological maltreatment ${ }^{1}$ of a child was integrated into the law. The definition is as follows:

"psychological ill-treatment" refers to a situation in which a child is seriously or repeatedly subjected to behaviour on the part of the child's parents or another person that could cause harm to the child, and the child's parents fail to take the necessary steps to put an end to the situation. Such behaviour includes in particular indifference, denigration, emotional rejection, excessive control, isolation, threats, exploitation, particularly if the child is forced to do work disproportionate to the child's capacity, and exposure to conjugal or domestic violence ${ }^{2}$. [4] 
The adoption of such a definition is the result of a collective process during which Quebec society, through its official entities and the Parliament, has come to modify its views on both children' rights and child abuse as well as the State's role in these situations.

Today, we note that practices in situations of child psychological maltreatment are considered particularly complex by social and socio-judicial professionals [5-8]. This complexity concerns the legal identification of the problem [9], its co-occurrence with several other social and family problems $[9,10]$, the dynamic and chronic nature of this form of maltreatment [11], and the adequacy of the programs and types of intervention used for other forms of maltreatment [11,12]. Child protection services' intervention is also subject to a number of criticisms, particularly with respect to situations of exposure of children to domestic violence and post-separation violence $[13,14]$.

Several authors link the difficulties encountered in situations of psychological maltreatment to the exceptional mandate of child welfare, more suited to situations where the consequences are physically observable and are the result of a more specific event, such as physical abuse [15-17]. For others, the importance of maintaining the curative rather than preventive focus of child protection explains why its intervention is limited in situations that present chronic, but not urgent, needs, as is the case in many situations of psychological maltreatment [10]. Very few have examined the formal definition of the problem and the representations on which its adoption has been based in order to better understand these difficulties. Changes in legislation or social policy are generally considered to be legitimate adaptations of the law to changing mores, to the discovery of new problems, or to new methods of intervention or investigation. For Habermas [18], this widely dominant type of reading is part of the proceduralist paradigm of law and is associated with the idea of "normatively expected democratic genesis of law" (461).

Various authors have underlined the important limits of such a reading, including Blumer [19], for whom the formal definition of social problems, such as child psychological ill-treatment, does not necessarily reflect a collective or a majority's opinion on the situation, nor is it the effect of a linear evolution. It is the result of power relations, contingencies, and complex dynamics that come to determine the given definition of the problem. For this author, when a formal definition is adopted, these often contradictory tensions come to be overlooked, giving us a (false) idea of consensus around a given problem and its nature.

In particular, other studies have shown that social representations play a major role in the choice of policy instruments implemented to address social problems (e.g., see [20] and the "problem of drugs") [21,22]. For Fairclough and Fairclough [23], since they provide reasons for action, representations (i.e., "descriptions, narratives, explanations" (p. 4)) have an eminently functional role that is often overlooked in research, in law, and policy making.

In the same vein, representations, which also correspond to the pre-existing understanding of contemporary society on various issues, are transmitted to policy makers and legislators through discursive exercises and deliberative sessions. These processes, in fact, should uphold democratic principles that "guarantee equal opportunities for the public use of communicative liberties" [18] (p. 296).

In the case in question, different social actors had, indeed, specific positions on the issue of including child psychological maltreatment into the law. In order to take into account the different points of view within society, various stakeholders were also invited to inform the government of their opinions and recommendations on the subject before the inclusion of child emotional maltreatment in the law. Indeed, 24 bodies, groups, or persons took a stance on the question and came to formally express their points of view before the modifications to the YPA were adopted. These hearings were held as part of a parliamentary committee ${ }^{3}$ organized for the introduction of the YPA amendment bill.

For us, the study of social representations mobilized during the parliamentary hearings at the time when psychological maltreatment was integrated into the YPA can allow us to better understand the difficulties encountered in the intervention practices of youth protection today. Drawing on a constructionist perspective on the development of social problems, we believe that this is a rich avenue for shedding new light on the complexity of 
today's practices and that such an exercise can be very useful for future decision-making in child welfare.

In this article, our objective is to document the social representations used by the stakeholders in the parliamentary committee to support their positions regarding the inclusion of child psychological maltreatment in the Quebec YPA. Furthermore, our objective is to document how these representations were instrumentalized in the defense of certain proposals for intervention with the families concerned by the problem. Moreover, we argue that these social representations, identified in the debates and controversies around child psychological maltreatment, also reflect the evolution of societal mentalities regarding the broader question of child abuse and the profound collective unease associated with it.

In order to meet our objective, we conducted a qualitative analysis of the hearings held in the parliamentary committee for the adoption of Bill 125 amending the Youth Protection Act. Before presenting our methodology and research results, it is important to clarify, in the next section, the most important concepts that guided our analysis.

\section{Conceptual Framework: Social Representations, Child Psychological Maltreatment, and Child Abuse}

The best way to understand how the problem of child psychological maltreatment is understood by the public and policy makers at a certain point in a society's evolution is to observe the knowledge, beliefs, opinions, and feelings that drive debates in society about this issue. The theory of social representations as developed by Moscovici [24] provides an understanding of this dynamic by offering a framework for explaining how people interpret, articulate, and appropriate the objects of their social and material world of which they are part. This theory assigns an essential role to common sense as an important element of what Giddens calls "practical conscientiousness" [25]. For Moscovici [26], social representation is thus a component of lay knowledge, a theory of common sense about a significant object for a social group.

Social representations are mobilized by actors in two ways [27,28]. First, they serve to give meaning to the realities they face. Moreover, they allow them to prescribe and organize their behavior in relation to these realities. This double nature, prescriptive and anticipatory, makes social representations dynamic because they allow the transformation of this social reality with which the actors are confronted. This dual use, which takes place in changing contexts, makes social representations not only dynamic and adapted to constantly changing circumstances, but also active in the construction of social reality and, more specifically, in defining what should be considered social problems [29].

As a result of the knowledge disseminated by the media, political actors, researchers, or ordinary people, social representations are formed through communication in different settings such as coffee shops, social networks, workplaces, family, but also public instances, such as parliamentary hearings. Through this communication process, what is initially unfamiliar becomes familiar and what is abstract becomes concrete and integrated into everyday life, for example, through laws, intervention practices, etc.

As explained by Moscovici [30], the social representation of any phenomenon, such as child abuse or child psychological maltreatment, is based on the pre-existing categories of our culture. Two communicational processes are at the core of the genesis and transformation of social representations: objectification and anchoring.

\subsection{Objectification and Anchoring of Social Representations}

Objectification is the process by which an abstract or unknown notion is transformed into a concrete object, perceptible through the senses and experience. Here, we discuss the example of Aurore, who has come to personify, and thus objectify, the worst-case scenario of child abuse. In Quebec, Aurore, a ten-year-old girl who died in 1920 from injuries and abuse inflicted by her mother-in-law, still dominates the collective imagination when it comes to child abuse [31]. The awful story of the Duplessis' orphans ${ }^{4}$ plays a similar role in the collective memory of Quebeckers when it comes to institutional abuse [31]. 
Anchoring is the mechanism by which a new representation becomes embedded in an already constituted network of social representations. It allows a new representation to be compared and interpreted by linking it to a network of already known elements. An example of the anchoring of child abuse is the nomenclature used by Kempe et al. [32] in 1962 in relation to the "battered child syndrome" to speak of the problem, which, in so doing, anchored that representational object in a network of pre-existing representations specific to the medical sphere and to disease $[33,34]$.

\subsection{Cognitive Polyphasia}

Once created, social representations come to be "the stuff" of common sense [35]. Moscovici also introduced the notion of cognitive polyphasia when explaining the plurality of sometimes contradictory social representations shared by a group or even existing within one person [24]. Indeed, he referred to the idea of the circulation of various ways of thinking related or attached to the same subject among groups and persons. This led him to establish a hierarchy of social representations: hegemonic, emancipated, and polemical [30]. Gillespie [36] further developed the distinction proposed by Moscovici, more specifically with regard to their level of dialogicity and the implementation of various discursive strategies when it comes to dealing with difference. As he explains, hegemonic representations are the contemporary equivalent of collective representations as developed by Durkheim; they are uniform, coercive, and globally unchallenged. Most importantly, they are "completely devoid of alternative representations" [36] (p. 382), meaning they do not actually deal with difference. The conception of child abuse seen as a major threat for the victims' future and as a risk that they become themselves adult abusers is an example of hegemonic representation in North America [33]. Indeed, politicians largely agree with the severity of the problem and the media also reported the idea of the transmission of child abuse from one generation to another as almost a certainty [33,34].

Emancipated representations circulate more freely within society. As shown in Gillespie's work [36], they also maintain a dialogical relationship with alternative representations. In other words, emancipated representations are discursively in contact with different views and other representations of a same object and with the possibility of having exceptions. Social representations of illness and health in traditional and alternative medicine are an example of emancipated representations [37].

At last, polemical representations "are elaborated in the context of an inter-group ideological conflict" [36] (p. 383). As a result, they generally present themselves in opposition to one major alternative representation. Discursively speaking, they tend to rhetorically react to this representation. In the literature on child protection services, the feminist positioning with regard to child abuse in the context of domestic violence is an example of polemical representation. This perspective tends to criticize the over-accountability of women, particularly with respect to the label of neglectful or unprotective mothers, when they are already victims of control and abuse [38,39]. Furthermore, it was elaborated in the context of a larger opposition to the patriarchal dominance of women as well as the patriarchal perspective on parental violence [40-42].

The hypothesis of cognitive polyphasia proposed by Moscovici in reference to the co-existence of various types of knowledge or thinking within the same person or the same group is particularly relevant in the context of public debates and more precisely in the context of a dialogue between members of the political sphere and others from civil society. Indeed, committee hearings have a special function in Quebec's parliamentary democracy since they allow people from civil society to take a stand and express their views on specific issues. In that sense, various types of stakeholders take the floor and, thus, we can expect different representations of a specific object to be put forward, such as representations of child psychological ill-treatment, child abuse, children, or parents. In the same vein, since a variety of actors are invited and allowed to defend their point of view on the same topic, different types of knowledge are also put forward simultaneously in these kinds 
of public settings (expert knowledge, community-based knowledge, field and practice knowledge, etc.).

\section{Materials and Methods}

\subsection{Research Questions}

This study seeks to answer three questions. In this context of public debates in hearings held in the parliamentary committee for the adoption of Bill 125 amending the Youth Protection Act: (1) What were the different stances of the stakeholders on the incorporation of psychological maltreatment into the YPA? (2) What social representations of children and parents can we identify in their discourse? (3) How did these representations feed into the different positions?

\subsection{Materials}

The hearings before the Social Affairs Committee constituted a singular way to identify the different stances that were taken on the incorporation of child psychological maltreatment into the YPA, as well as reactions and recommendations. First, we collected the transcripts of all the hearings in the Quebec National Assembly archives (see http: //www.assnat.qc.ca/fr/travaux-parlementaires/journaux-debats/index-jd/41-1.html, accessed on 15 January 2020). Each of the 9 days of hearing corresponds to a pdf document of between 130 and 166 pages. Between 7 and 9 stakeholders spoke per day of the hearing. Then, we selected testimonials from stakeholders taking a position on the incorporation of child psychological maltreatment or amendment of Section 38 of the Act. Over the 9 days of hearings, 24 bodies, groups, or persons raised these subjects. They also pertained to various types of organizations, such as community-based organizations, advocacy groups, research institutes, independent government agencies, etc. The names ${ }^{5}$ of each group, organization, or person, as well as their organizational type, are exposed in Table 1 . They will be referred to by their attributed number in the rest of the text. Questions and statements made during the hearings by Minister Delisle, who sponsored Bill 125, henceforth referred to as M.D., were also analyzed.

Table 1. Stakeholders and their type.

\begin{tabular}{|c|c|c|}
\hline$\#$ & Full Name & Type \\
\hline 1 & Assembly of First Nations Quebec-Labrador & Advocacy group \\
\hline 2 & Association of Parents of Children Monitored By The Youth Protection Directors & Advocacy group \\
\hline 3 & Attachment Clinic of the Sainte-Justine University Hospital Center & University Hospital Center \\
\hline 4 & Awareness Raising for a Better Childhood Movement & Community-based organization \\
\hline 5 & Confederation of National Trade Unions & Central union \\
\hline 6 & Council for Children and Families & Independent government agency \\
\hline 7 & Hochelaga Maisonneuve Youth Working Table & Community-based organization \\
\hline 8 & Human Rights Commission and the Youth Protection Commission of Quebec & Independent government agency \\
\hline 9 & Information Centre on New Religions & Community-based organization \\
\hline 10 & Laval Women's Centre & Community-based organization \\
\hline 11 & Legal Services Board & Advocacy group \\
\hline 12 & Mr. McCauley & Individual \\
\hline 13 & Professional Order of Social Workers of Quebec & Professional Order \\
\hline 14 & $\begin{array}{c}\text { Provincial Coalition of Shelters and Transition Houses for Women Victims of } \\
\text { Domestic Violence }\end{array}$ & Association of community organizations \\
\hline 15 & Quebec Association of Health and Social Services Establishments & Consortium of public bodies \\
\hline 16 & Quebec Bar & Professional Order \\
\hline 17 & Quebec Central of Trade Unions & Central union \\
\hline 18 & $\begin{array}{c}\text { Quebec Federation of Shelter Resources for Women Victims of Domestic } \\
\text { Violence and Women in Difficulty }\end{array}$ & Association of community organizations \\
\hline 19 & Quebec Order of Psychologists & Professional Order \\
\hline 20 & Quebec's Youth Center Association & Consortium of public bodies \\
\hline 21 & Research Institute for Youth Social Development & Research institute \\
\hline 22 & Ste-Justine University Hospital Center & University Hospital Center \\
\hline 23 & University Institutes & Research institute \\
\hline 24 & Youth Protection Directors & Consortium of public bodies \\
\hline
\end{tabular}




\subsection{Analysis}

We used the analytical questioning method as proposed by Paillé and Mucchielli [43] in order to identify and organize the different representations that were relevant to the stakeholders' positioning and that were instrumentalized in their discourse. It is particularly well suited to research that is based on relatively specific research questions and clear theoretical hypothesis, as opposed to research that is more exploratory in nature [41]. When this is the case, this method of analysis of qualitative data has the significant advantage of avoiding arduous and long coding work that is not always useful.

This method consists in creating a dialogue between the analyst and the data they are investigating, in the Latin etymological sense of the word "inquester", which means "to ask". Researchers who use this method build an investigative canvas that will gain precision and relevance throughout the analytical process. As Paillé and Mucchielli explain, "[... a large part of the analytical strategy in analytical questioning analysis consists of constantly asking new questions [...] until the investigative canvas is sufficiently discriminating and the various elements of the answer can be gathered, detailed and finalized" [43] (p. 214, Transl.).

To give an example, some of the initial investigative questions read as follows: Which families are being considered in the development of the YPA amendments? How are they represented in the stakeholders' statements? In later versions of the investigative canvas, this question was branched into several sub-questions: Which families, and more specifically which members, are included and directly affected by the amendments? Which ones are excluded? What images are used to describe them? Are these images linked to other social issues? Which ones? Etc. Finally, in the final outline, we could read questions such as: Can we organize the discussion according to the degree of individual responsibility attributed to parents? What parental interests or concerns can we identify in the stakeholders' discourse?

In this extent, the analytical questioning process entails the examination of research data at least three times in order to produce responses. A first exploratory examination allows us to get acquainted with the data and to enrich the initial investigative framework; a second examination allows the consolidation of the framework by reexamining various elements with new questions; a third review enables the validation of the proposed analysis [43]. The analysis of the data thus proceeds from several successive back-andforth movements between the investigative framework, the research objectives, and the theoretical framework of social representations.

Ultimately, the final canvas consisted of the following sections: (1) stakeholders' positioning with regard to the incorporation of child psychological maltreatment into the law; (2) the social representation of the children concerned; and (3) the hegemonic, emancipated, and polemical social representations of the parents concerned.

\section{Results}

In this section, we will present the results of our analysis, starting with the different positions taken and the issues raised during the parliamentary commission's hearings with regard to the incorporation of child psychological maltreatment.

\subsection{Issues Related to the Incorporation of Child Psychological Maltreatment into the Law}

With regard to the incorporation of child psychological maltreatment into the law, 19 of the 24 stakeholders who expressed an opinion admitted to being in favor of the modification. Out of the five remaining, two were unfavorable. The last three did not specifically talk about psychological maltreatment but expressed their concerns about the modification of article 38 in general, as well as the inclusion of clinical features into the law.

For those in favor, the incorporation of child psychological maltreatment was going to help clarify the intervention, for example by allowing to clearly state the problem within families' intervention plans $(3 ; 21 ; 24)$. 
I'm the one who will evaluate the situation, taking into account the facts that are reported to me, but we open our eyes; we look. And that's why we already see psychological abuse, but we don't have the leverage to really put protective measures in place specifically for that aspect. $(21)^{6}$

In addition, the main reason for supporting the inclusion of psychological maltreatment in the law was its impacts on children (such as impacts on self-esteem, problems in the development of identity, mental health issues, insecure attachment disorder, or behavioral disorders, etc.) $(15 ; 7 ; 24 ; 21)$. Many stakeholders also compared child psychological maltreatment to child physical abuse with regard to their consequences $(21 ; 15 ; 18$; 20). Nevertheless, we noted some ambivalence with regard to the various forms of child psychological maltreatment. Certain situations were described as unmistakable and were put forth as support for the consensual depiction of child psychological maltreatment.

[... ] we know the psychological needs of the child. We all know that our needs are frustrated in our development, we expect that, but the basic needs... For example, if the child was constantly subjected to attacks on his personal image, even... well, there are things like that, it's big, it's obvious that he won't be able to develop the minimum self-esteem necessary to be mentally healthy. (19)

This idea of social consensus around the consequences of child psychological maltreatment also sheds light on the fact that certain forms were also more consensually identified and recognized as abusive than others, notably emotional rejection and denigration. At the same time, comments have also shown that some questionable verbal behaviors should still be tolerated and distinguished from maltreatment: "There are behaviors that are not beautiful, but it is not those behaviors for which one necessarily needs state protection" (21). "Yes, this situation is psychological abuse, and this one, well, it's more of the order of bad behavior, as I call it "(21).

Even when they were in favor of the incorporation of child psychological maltreatment into the YPA, many stakeholders (12/19) still had some concerns. We classified those concerns into two categories: (a) child psychological maltreatment identification criteria and (b) specific issues related to child exposure to domestic violence.

(a) Concerns related to the identification of child psychological maltreatment

With respect to the first category, we noted that, even if they were globally in favor of the modifications, certain groups pointed out the lack of clarity of the definition as written in the bill and called for caution $(23 ; 18 ; 19)$ :

[...] we welcome the fact that this concept has been included in the law. However, we call for great caution. Evaluating what psychological abuse is requires skills, so that the person who evaluates it takes the right measure: Is it such abuse that the attachment relationship should be broken? (19)

The definition of "psychological maltreatment" also contains a good deal of vagueness about the criteria, including what level of indifference must be reached to trigger YPD intervention. (23)

For others, the list proposed in the amendments was too limited to meet the children's need for protection. The Legal Services Board (11) even went as far as to stand against the amendment on the basis of the rigidity of its formulation:

It appears to us that the proposed amendments are intended in some cases to restrict the application of the Act, as in paragraphs b and f, and in other cases to make it much more rigid, as in paragraph c. (11)

On the opposite side, other groups were concerned that child psychological maltreatment could, in practice, become a "catch-all" clause and focused on the caution that its incorporation required.

But I think we have to limit ourselves to the judgment that we could have of an immediate [and] circumscribed impact. Otherwise, we don't make it, I mean... (23) 
We think that this wording could correct a number of the problems I mentioned earlier and also prevent paragraph c of Section 38 from becoming a kind of catch-all category where everything can fit indiscriminately. (21)

\section{(b) Concerns related to child exposure to domestic violence}

The second category of limitation that was pointed out concerned more specifically the problem of children's exposure to domestic violence. On the one hand, some stakeholders noted that children who are exposed to domestic violence were not victims only of psychological maltreatment, but were in some cases victims of physical abuse, sexual abuse, or neglect. Even though the explicit mention of exposure to domestic violence was appreciated, its identification as a form of child psychological maltreatment was criticized and seen as insufficient.

The explicit inclusion in the Bill of the grounds of compromise such as indifference, denigration, emotional rejection, etc., resulting from conjugal and family violence, which are all indications of psychological abuse, is certainly to be welcomed. However, we would have liked to see these provisions also include children who are victims of multiple violence, such as sexual, physical, psychological, verbal, and economic violence. These are severity criteria that should have been clearly specified [...]. (18)

Sometimes the mother will be accused of engaging in parental alienation because she is trying to protect her child and doesn't necessarily want the child to see the father at all or to see the father under supervision. (18)

In the same vein, the general lack of consideration and knowledge concerning specificities and difficulties of domestic violence within child protection services, as well as within the proposed amendments, was the subject of criticism. More specifically, the lack of recognition and knowledge concerning impacts of domestic violence on mothers by youth protection workers was mentioned in this context $(18 ; 14 ; 2)$.

For the Laval Women's Center (10), the risk of re-victimization ${ }^{7}$ for mothers was so significant that they stood against the inclusion of children's exposure to domestic violence in the YPA.

We therefore recommend that exposure to domestic violence not be named as a reason for intervention, but that the Domestic Violence Intervention Policy be applied in all YPD interventions, as well as mandatory screening as recommended in the policy.... that the YPD also recognize and enshrine in law that, in cases of children exposed to domestic violence, there are two victims: there is the mother and there is the child. (10)

\subsection{Social Representations of the Children Concerned When It Comes to Youth Protection}

The social representations of children that we observed in the discourses were very similar from one group to another and pointed to the same traits-mainly vulnerability and innocence. References to children highlighted their great vulnerability. Not only were children seen as vulnerable in general, but the children targeted by youth protection services were also depicted as constituting a particularly vulnerable and defenseless minority. Of note, the association of childhood with vulnerability was consensual across the stakeholders, as well as parties' elected members. Apart from that, some stakeholders paid particular attention to issues that concerned them more specifically when it came to representations of children affected by the YPA. For example, Sainte-Justine University Hospital (22) pointed out the numerous health problems that these children were often facing. The attachment clinic of the same hospital (3) specifically talked about children with attachment disorders.

The children were also objectified in the discourses, with one image taking a heightened place: the tossed children. Many actors referred to the frequent moving of children between various care settings as a priority issue to address. True stories in which children 
were given fictional names and personified were narrated in order to describe the problem of unstable living arrangements of children and its severity.

Another notion came into play and supported the opposition between children's and parents' needs, namely, the importance of distinguishing between time for children and time for parents.

You know, maybe 12 months, 18 months, 24 months: it's not a lot of time for a parent to get their act together; it's a short time, but for a child it's a long time. (6)

An adult can take two years to recover from an unhappy childhood, from a major emotional problem that prevents them from taking good care of their child. But, in the meantime, what do we do with that child? We can't put the recording on "pause" and say: Well, wait until your parents are better to develop and attach to you, wait until they come back. We can't do that. (3)

However, there is another reality beside that: there is the child's time and there is the adult's time. (3)

Moreover, the majority of the stakeholders paid a great deal of attention to early childhood in their speeches, stating, for example, the importance of the quality of care received in the early years throughout an individual's life $(3 ; 19 ; 21)$.

We observed a distinction between young infants and teenagers in the discourses. Indeed, infants' descriptions triggered the idea of purity, like a clean slate, whereas teenagers were described as troubled, stressing that, from a representational perspective, they did not evoke the same level of empathy $(11 ; 7 ; 15 ; 19)$. With regard more specifically to child psychological maltreatment, we also noted some ambivalence concerning teenagers. Indeed, the figure of the "troubled teenager" was used sometimes, mostly by Minister Delisle herself, in order to distinguish child psychological maltreatment from unfortunate, but understandable, bickering between a parent and their teenage child.

Lastly, some groups discussed the more universal perspective of children's rights (13; 19), sometimes explicitly stating that they should be prioritized over their parents' rights $(6 ; 4)$.

We mentioned earlier that the opposition between children's rights and parents' rights tainted the development of Quebec's youth protection services early on. Officially speaking, the children are the only targeted population of the YPA, and their potential need for protection was not up for debate. Indeed, their vulnerability was also closely related to various statements evoking a collective duty to protect them. Of note here is that this unique representation of children as defenseless victims was used to support various positions, including contradictory ones. For example, a group claiming that victims of child abuse should be placed in foster care faster relied on representations of children as innocent and vulnerable beings just as much as another group claiming that the exact opposite, namely that more efforts should be undertaken to keep the children in their primary families. What varied a lot more within the groups were the social representations of the parents associated with their statements and arguments.

\subsection{Social Representations of the Parents Concerned When It Comes to Youth Protection}

Our analyses allowed us to identify different social representations of the concerned parents in the stakeholders' discourse and rank them hierarchically using Moscovici's typology, i.e., hegemonic, emancipated, and polemical social representations [30,36].

First, we will detail these different types of representations in order to show how they were used in the discourses. Particular attention has been paid to their correspondence with the different cases of Moscovici's typology.

\subsubsection{The Dangerous Parent}

We call the first parental figure that emerges from the discourses the dangerous parent. This figure consists of two facets that can be viewed as two sides of the same coin: (a) on the one hand, the harmful parent and (b) on the other hand, the "neglected" parent (parents 
who were neglected during their own childhoods). Both were considered as great danger to their children and were attributed a high degree of individual responsibility with regard to child abuse.

\section{(a) The harmful parent}

Starting with harmful parents, they were sometimes referred to as heartless and were described in terms of their behaviors and actions. They were also described as grossly irresponsible and as showing a grave lack of empathy for their children. In some discourses, the danger for children was also emphasized by using references to well-known and gruesome cases of severe child abuse (4).

Otherwise, parents were referred to as potentially dangerous for their kids in different ways, which involved parental behaviors and attitudes. Here, many examples were given in order to illustrate what is considered as seriously wrong decisions taken by parents, in particular mothers:

The mother asks her child to see his father despite the ban on contact. She puts him in the presence of the latter and, because of her actions, she loses her place in the shelter. The child is moved again. (20)

A baby born in January 1994 is reported to the director of youth protection as soon as he is born. The reason: his mother was hospitalized a few weeks before his birth; she had consumed cocaine throughout her pregnancy. This mother has three other children who are all housed in the facilities of the youth center. (20)

Parental refusal to be helped was also presented as a potentially serious danger for children. For example, the Quebec Order of Psychologists (19), as well as the attachment clinic of the Sainte-Justine University Hospital Center's representatives (3), referred to problematic parents as those who would not ask for help or accept it even if they needed it:

Someone said to me earlier: Yes, but these parents are not going to call the CLSC to see a psychologist because they are having trouble with their child, if they have been on drugs... Yes, I believe that, that they won't call to say: I'm having trouble with my child. (19)

... but there is a certain proportion of the population that does not respond to these approaches, that bypasses them. And I can tell you that, in the 12 years of the Attachment Clinic, we have seen many more people who have refused services than people who have not been offered services. (3)

Noteworthy are the numerous references to drug addiction when exemplifying harmful and dangerous parents. From a representational perspective, these examples allow both the objectification and anchoring of the social representations of parents under the supervision of youth protection services. Indeed, these examples give a clear picture of the problem and allow the anchoring of social representations of abusive parents into a network of already existing social representations related to drugs and addiction (also see $[29,44,45]$ on the social construction of drugs as a public problem). These examples, as well as their numerous occurrences in some stakeholders and in Minister Delisle's statements, point to the role of pre-existing representations in the process of framing the problem by selecting information related to the object of representations [29].

\section{(b) The "neglected" parent}

As for the harmful parent, the figure of the neglected parent emphasizes individual responsibility as well as dangerousness, but also integrates elements of compassion for the parent. The distinction also rests on the fact that stakeholders suggested some explanatory factors concerning parental limitations, such as their own experiences of abuse when they were children:

And often, if we look at the history of parents from whom children are taken [...], it is often young people who were accompanied 20 or 25 years ago by the YPD. 
[...] When a child is taken away, they are removed from their family's home, for $x$ reasons, and then the parent is told, given an order: You must achieve such and such objective. But who is in charge of showing them the means to achieve the objective? Because, if they are not able to reach the objective, it is because they often do not know how to get there. (7)

Here we are talking about extreme situations: someone who has been so deprived themselves that they are not able to put themselves in the position of the child and to respond to their needs. (19)

In the previous category, the comments referred to situations in which parents were represented as not wanting to be helped, whereas in this category, parents are represented as not being able to be helped:

After a few months of intensive intervention, we instead often encouraged and accompanied parents to report themselves [to the YPD] because the depth of their suffering prevented them from adequately performing the parental role, and their wounds sometimes take so long to heal [...]. (4)

A parent who has mental health problems, who has substance abuse problems, who has suicidal thoughts, they need their child to be taken care of. (4)

The image of the drug-addicted parent was also used many times in reference to the neglected parent. Indeed, we also noted many references to this image in Minister Delisle's statements. In fact, the image of the single drug-addicted young mother was used many times throughout the hearings in order to distinguish the willing parent, ready to receive help, from the parent who does not want to be helped. The aforementioned observations in relation to the use of the drug-addicted parent in order to objectify as well as anchor the representation of dangerous parents stands in this case, with the addition that examples with regard to the neglected parent specifically refer to young and single women. Thus, we noted that the representation of dangerous parents, both harmful and neglected, is not anchored only in the discourse within an already existing network of social representations related to drugs, but also to another discourse related to the image of the teenager "daughter-mother". Here, it is important to mention that the daughter-mother has historically been seen as morally incapable, debauched, and globally suspect in Quebec, mostly because of the clergy's discourse on the sin of lust and on the mothers of children born out of wedlock [36,46-49].

Minister Delisle also often provided examples related to parental limitations or difficulties, in general those of mothers, in order to illustrate the need for services, but mostly in order to distinguish which situations should receive help and which should not: "[...] the mother who is suffering from mental health, depression, either postpartum or some other type of depression, burnout, or a mother who finds herself... who is forced to finally report... go to a shelter..." (M.D.).

The last quotation shows that explanatory factors such as depression, burn-out, or domestic violence are considered to be legitimate.

Lastly, various elements show that the figure of the dangerous parent, whether it is the harmful parent or the neglected parent, constituted a hegemonic representation in the hearings. First, these images were particularly present in the discourses of Minister Delisle, as well as other governing party members and oriented their stances in every step of the passing of the Bill. More importantly, the hegemonic representation of the dangerous parent, as we will see in the next sections, does not allow for sufficient dialogue with other representations of problematic families. As explained by Gillespie [36]: "we can characterise hegemonic representations as completely devoid of alternative representations. In this sense, hegemonic representations are completely egocentric, and they orient to and dialogue with no alternative perspectives" (p. 382). 


\subsubsection{The Destitute Parent}

Another representation of the parents arose from the stakeholders' discourse, which we called the destitute parent. This figure referred to parents living in poverty, exhausted parents, or unlucky parents who are the victims of bad circumstances. It referred, broadly speaking, to the various, numerous, and complex difficulties parents could be facing when raising a child. Here, actors adopted a more critical stance with regards to the families' many difficulties and drew attention to various elements other than individual responsibility. It is important to note that stakeholders here did not minimize the gravity of child abuse, nor did they justify it, but their comments came as an effort to nuance the individualistic interpretation of child abuse. Thus, the figure of the destitute parent does not deny the existence of dangerous parents, but rather questions their predominance within the discussion concerning child protection. This representation can be categorized as emancipated. To quote Gillespie again, "[...] emancipated representations circulate with a degree of autonomy in the society. Emancipated representations are forged in the context of a field of diverse alternatives" [36] (p. 382). Thus, we noted that stakeholders' representations referring to the emancipated representation of the destitute parent put forth various elements related to parents seen as vulnerable, starting with poverty and bad living conditions $(1 ; 7)$ :

On the other hand, we are well aware that extreme poverty weighs excessively on a parenting environment, and that is why, in addition to the child protection Act, there should be, on the part of our governments and our rulers, very special attention paid to the conditions in which poor people live, whether it is housing, whether it is lack of recreation, whether it is an education that is not completed, whether it is the availability of parks, so that children do not live in corridors or in inappropriate places. (3)

Too often the economic distress experienced by parents undermines the functioning and stability of the family unit. (13)

Bureaucracy, such as the complex welfare system, long waiting lists, or administrative burdens, was also cited as contributing to parental destitution (17):

So those services are needed. You have parents who are addicted and who, with the right support, can keep their children. On the other hand, you have parents who are addicted who have to wait three months, four months before they get services. (13)

[...] because we will have to ensure that the CSSSs will be available to serve families who, if they do not receive help quickly or intensively, see their situations worsen to the point of requiring much more expensive services or reaching a point of no return. (24)

Other stakeholders did not relate the problems to any specific element but pointed out to the complexity of the situations, their variability, and the difficulty, even impossibility, of clearly and procedurally stating what should or must be done:

To make parallels with healthcare, sometimes... We know now that if you go to the hospital for an appendectomy, it's a one-day surgery; you go home. There are time frames that are very fixed. In the case of re-establishing parenting, ...getting the complication out of the way, it doesn't always get cut with a knife. (13)

$[\ldots]$ it is now recognized that children's difficulties are rarely associated with [only] a family problem. The reality is usually more complex than it appears to be at first glance. Similarly, the seriousness of the situations and therefore the urgency of stopping certain behaviors and putting the protection of the child ahead of all other considerations varies significantly from one case to another. (8)

Of note, here again, the image of the drug-addicted parent was used but referred to an open representation of parentality where the drug consumption is not automatically associated 
with untreatable bad parenting but is rather seen as an indication of a need for guidance and accompaniment. The complexity and variability of the situation were also emphasized, pointing to the more flexible and dialogical character of this emancipated representation.

\subsubsection{The Powerless Parent}

Lastly, another social representation of parents was observed and used in the discourses. It referred to parents' lack of power, which we named the figure of the powerless parent, and constitutes a polemical social representation.

Here, stakeholders referred to the power differential between the families, the State, and the YPD:

Legal aid lawyers are able to see in their court practice the degree of vulnerability of children and parents who are confronted by state agents in the application of the YPA. (11)

[...] $72 \%$ of children's situations where safety or development is compromised involve problematic adults; we must [therefore] address the real abuse of power of fragmented services and unstable workers to [...] recognize, value, and support workers. (5)

As in the previous category, structural elements were criticized and put forward in order to shed light on parental limitations and vulnerability. The polemical aspect resides in the lack of possible dialogue with other representations and the rigid opposition with one predominant and hegemonic representation of the dangerous parent. Indeed, polemical representations are elaborated in the context of inter-group ideological conflict [36]. In other words, the emancipated representation communicates the message that dangerous parents have to be considered, but may not be the focus of our efforts, whereas the polemical representation says that dangerous parents are not the real problem, but that power asymmetry is. Moreover, even if it was not explicitly developed in the stakeholders' discourse, the polemical representation of the powerless parent rests on an implicit narrative according to which power asymmetries are at the root of families' difficulties.

In our opinion, this ideological opposition is even clearer with regards to criticisms brought forth by some stakeholders concerning child protection services' treatment of women:

She's not a bad mother; she's a mother who is disconnected from her responsibilities because of her survival instinct, always watching that the children don't make too much noise in the house because it could irritate the man and if the man gets irritated, well, there's going to be an escalation in violence. (18)

We notice that, when the YPD interveners feel that the child's needs have not been met, they immediately turn to the mother. [...] We want a system that will protect children, but we are worried that the mission of this system will be diverted to exercise a form of social control that will lead to a narrow perception of what education is, or what a good mother is, or what the values that we want to transmit socially are. (10)

A clear effort of persuasion is made by these stakeholders to show that women's behaviors are wrongly interpreted in the context of domestic violence and that the YPD has greater expectations from mothers compared to fathers. In both situations, power asymmetries are seen as the real problem that should be focused on.

Finally, the following table summarizes the various social representations of the parents concerned by the YPA, identified in the stakeholders' discourse as well as in Minister Delisle's statements (see Table 2). 
Table 2. Types of social representations of the parents, images used, and related claims.

\begin{tabular}{cccc}
\hline SR Type & Parental Figure & Images & Claim \\
\hline Hegemonic & $\begin{array}{c}\text { The dangerous } \\
\text { parent/The neglected } \\
\text { parent }\end{array}$ & $\begin{array}{c}\text { Killing parent/drug-addicted parent } \\
\text { (mostly mother)/Daughter-Mother/The } \\
\text { "good" and the "bad" poor }\end{array}$ & $\begin{array}{c}\text { A dangerous parent does not } \\
\text { deserve to be helped or only } \\
\text { deserves to be helped in specific } \\
\text { circumstances. }\end{array}$ \\
Emancipated & The destitute parent & Variable/Unclear & $\begin{array}{c}\text { Understanding parental } \\
\text { situations requires nuance and a } \\
\text { margin of discretion in practices. }\end{array}$ \\
Polemical & The powerless parent & (of the system, of patriarchy, of ... ) & $\begin{array}{c}\text { A powerless parent deserves to be } \\
\text { helped within a bigger project of } \\
\text { social and structural changes. }\end{array}$ \\
\hline
\end{tabular}

\section{Discussion}

As explained above, representations have different functions in communications, among them supporting certain courses of actions and claims [23]. Our results also support the observations and theoretical hypotheses of Moscovici [30] and his successors (e.g., [32,49,50]), in particular that social representations, due to their plurality, make communication and reflection on certain topics possible and others impossible [49]. In other words, our collective capacity to think about certain issues and consider different solutions is highly dependent on our ability to see them from different angles, to explore different facets and perspectives. For Fairclough and Fairclough [23], it is also in good part on this capacity to consider the representations of a present or projected situation contained in the counter-arguments that the ethics of a political discourse rests. Habermas [18] also emphasizes these dialogical aspects in the exercise of deliberation. Otherwise, communications would be monological and technically void of transformation possibilities.

Thus, the uniqueness of the social representation of the child as a defenseless victim is the first element we wish to focus on. It reflects a major change in the conception not only of the family [21] but also of the child as a potential target for public action. Indeed, from a historical perspective, many authors agree that during the last decades of the nineteenth century, the collective perception of children and the social practices surrounding them have changed drastically [1,51-53]. For example, around the end of the nineteenth century, the exploitation of children at work came under severe criticism in Western countries [52]. Vagrant children were also a problematic population, especially in cities in the United States and England [52]. In other words, children have changed from a population that was perceived as having to be controlled and, to a certain extent, "bought" and used, to a population that needed to be helped and protected [1,51-53]. Even if we look more precisely at the children who were already targeted by some forms of public action in North America, Lacasse explains that: "[...] the conception of young guilty vagrants disappears over the centuries and is replaced by a representation of the child victim as innocent and malleable" [48] (p. 72, Transl.).

In 1985, Zelizer [53] developed the notion of sacralization when referring to this new view of the child, which has developed between the 1870s and the 1920s in North America [54]. The child seen as priceless, a gem, in contemporary Western cultures, is opposed to the utilitarian perspective on children, seen not long ago as a potential workforce $[55,56]$. Segalen and Martial also refer to parents' new social roles with regard to the education of the "contemporary sacred child" [55] (p. 155, Transl.): it is not a question of feeding and disciplining the child, but of nurturing and loving them in order to let them become autonomous and unique individuals.

Hence, contemporary society has come to "invest" symbolically into children, who then became symbols of success and the proof of an accomplished adult life [51,55].

Furthermore, this sacralization process of the child also has importance for our conception of child abuse [33]. If a child is now sacred, then to be violent towards them (physically, 
sexually, or emotionally) is not only a mistake, but also, as Hacking puts it, an "ultimate evil" [33] (p. 135). In other words, child abuse has been tabooed not only at the behavioral level, but also at the conversational level [57].

Indeed, the sacralization of children also implies that no debates are possible with regard to child abuse. From a representational perspective, it reminds us that in order to enable communication, social representations actually need to be plural [58]. As summarized by Gillespie "[... ] although there needs to be a shared context for communication, there also needs to be some difference between the speakers otherwise there would be nothing to communicate about" [36] (p. 378). In our analysis, the fact that the social representation of children was so consensual and undisputed can be seen as a reflection of the taboo that child abuse constitutes in our society [33].

This reminds us of Turmel's suggestion when he talked about the little Aurore and the Duplessis' orphans as stereotypes representing the "children of the margin" in Quebec's culture: "These categories nurture the miserabilist image that saturates our imagination, to the point of preventing us from hearing another voice" [31] (p. 306, Transl.). As we explained earlier, these images also played an important part in the anchoring and objectification process of child abuse in Quebec. Thus, our results show an interesting paradox, which is that even though the children in danger are formally the only targeted population of the YPA [21], the social representations shared by the actors taking a stance concerning the modification of the law do not actually allow any debate or discussion about the children per se, or about the definition of child abuse. This reminds us of not only the behavioral interdiction around any taboo, but also of the conversational ban surrounding it [57].

The practical implications for the development of child welfare law and social policy are, in our view, of great importance since the inability to discuss and debate sensitive issues, even in spheres that are reserved for this exercise, risks maintaining potentially harmful and unjust assumptions, attitudes, norms, and implicit normative injunctions very active in our collective response to the problem.

This brings us to the fact that the elements that were debatable and led to various positions during the hearings were related to the figure of the parents, and furthermore, to whether or not they should receive help. In practical argumentation's terms, representations of the parents were the reasons for action and the basis for divergent claims.

Here, we would like to focus on the hegemonic representation of the dangerous parent and explore some reasons that could explain its hegemonic status, starting with historical elements. Indeed, parental responsibility in relation to child abuse, both the duty to protect the child and the responsibility of the parent as the primary perpetrator of abuse, is even more recent than the sacralization of the child. For Hacking [59], the identification of the abusive parent is directly related to the emergence of the medical model of abuse, a model that took off in the 1960s following the publication of Kempe, Silverman et al.'s ground-breaking article "The Battered Child Syndrome" [32]. These authors were the first to put forward the hypothesis of what would later be called the intergenerational transmission of abuse; the idea that a child abused by their parents would in turn become an abusive parent. Shocking as the idea may be (before the 1960s, the idea that parents were the primary perpetrators of abuse was not prevalent), its explanatory power quickly gained currency and became a generalization about the phenomenon of child maltreatment [59]. The idea of intergenerational transmission of abuse, widely disseminated in the media, allowed anyone interested in the problem to associate a culprit with it as well as an etiological explanation linked to individual responsibility, one of the flagship principles of American liberal society [60]. To reiterate our idea that child abuse is a taboo in postmodern Quebec society, identifying the parent responsible for child abuse also protects against the contagiousness of the taboo [57]. Hence, one important reason that could explain the hegemonic status of the social representation of the dangerous parent is its capacity to distinguish the group who adopts this representation from the individuals who are "othered" as dangerous parents. In other words, the primary force of this representation could be to protect the social identity of the group who shares it [61]. In addition, this may 
also provide a better understanding of why the protection system continues to deliver such uneven services across the population [62].

As mentioned before, one image rose more often than others concerning abusive and dangerous parents: the single drug-addicted mother, which served many times to distinguish the deserving parent (she wants to be helped, is ready to enroll in therapy and responds to recommendations, etc.) from the non-deserving one (she has bad habits, she is negligent). Here, we can see traces of the old image of the teenager daughter-mother [45], as well as the distinction between the good poor and the bad poor $[61,63]$ in the religious society of Quebec in the past. As explained by Moscovici, anchoring and objectification of social representations occur in a given cultural setting [24,30]. Indeed, the categorization of families reminds us of the distinction already noted by Turmel [31], Lacasse [48], and Bouffard [47] with regard to the placement of children at the beginning of the twentieth century in Quebec. For Lacasse [48], this categorization is the reflection of the stigmatization of working-class families, seen as immoral and irresponsible [64]. As Lacasse explains with regard to the categorization carried out by nuns:

The Church and the State thus allowed themselves, through these descriptions, to stigmatize families. Indeed, it appears that [...] some mothers are "suspicious", and some parents don't effectively supervise their children. However, other families have "overburdened" mothers; one of the two parents is experiencing "temporary difficulties" [...]. In short, the intervention of the State and the Church in the name of the interests of the child [...] implies a right of supervision and thus carries with it a stigmatization of working-class families. [48] (p. 171, Transl.)

The similarities between these various historical elements and the hegemonic representation of the dangerous parent we identify in the results tell us that the social need to categorize abusive parents as well as to protect the group from any association with them is still very salient. Interestingly, the explicit purpose may have changed (from implementing God's teachings to protecting children's rights), but the targeted population and, more importantly, the people who are seen as culpable and even malicious are virtually the same.

Finally, these observations can also be linked to the polemical representation identified, that is, the feminist representation describing the consequences of the social control that weighs on women and that, by the same token, reproduces a form of symbolic violence against them [65]. These elements are in line with various criticisms that have been made of child protection systems, particularly with regard to their intervention in situations of domestic violence and their treatment of women $[39,66]$. Some authors went as far as to state that child protection systems are much more effective in controlling families deemed deviant than is social assistance (see [59]). In all cases, it is the structural reproduction of asymmetrical power dynamics that works to the detriment of marginalized populations, particularly women who, following a gender-oriented and legalist reading of parental responsibilities, remain over-responsible and unjustly identified as the primary ones in charge of their children's education, care, and protection $[60,67,68]$. In this respect, it is interesting to note that, even when they recognize the importance of helping women in need, the comments of many stakeholders, as well as Minister Delisle herself, show that the hegemonic representations of the dangerous parent contribute to maintaining the effects of this symbolic violence; women are still considered to be individually responsible for the conception of a child, their birth, and finally the (mal)treatment they receive.

In light of these results, it seems important to emphasize that, despite the official intention to develop a protection system based on the objective and neutral identification of compromised situations, the hegemonic representation of the dangerous parent enables the implementation of actions that target marginalized groups, allows for their surveillance, and then makes possible coercive interventions aimed at them, in particular the removal of a child from their family environment and/or the tight control of parenting practices.

Thus, the complexity of practices in psychological maltreatment situations are not necessarily only related to the application of the mandate in these situations or to their mere unobservability. They are potentially linked to a mismatch between practices and the 
representations of both parents and children on which the law is based. This hypothesis could be the subject of future research.

With regard to the development of social policies and laws, we believe that an awareness of the existence of such representational dynamics contribute to developing a certain openness to multiple and plural family realities and their difficulties. If child welfare systems are to cease reproducing social inequalities, we need to understand how this reproduction takes place, especially through the social representations we have of families as well as through strict, conservative injunctions and norms (see also Burlone and Couture [22] for a similar reflection about family policies). In particular, our research allows us to understand how these representations may obscure other possibilities, other actions, to respond to the problem. In view of the hegemonic representation of the dangerous parent, it appears practically immoral to consider providing additional assistance to families as a solution. In this extent, if policy makers and legislators do not challenge the representations of parents that underlie their choice of policy and legal instruments, they are in a sense doomed to reproduce structural injustices.

\section{Limitations}

This study has some limitations; first, in relation to the type of stakeholders who expressed their views. Indeed, the majority of the participants were specialists, experts, or jurists, while very few parents or children were heard. This over-representation of experts' points of view has necessarily tainted our results, which cannot therefore be transposed to the general population or the people who are directly affected by the law. Similarly, the material analyzed does not give us access to the public's reaction to the recommendations issued and the social representations that support them. Finally, although we can suspect the influence of the representations identified on the youth protection sector, our analyses do not allow us to know the effects on intervention practices.

\section{Conclusions}

The objective of this article was to explore the role of social representations in the discourse of different stakeholders during the public hearings that preceded the incorporation of child psychological maltreatment into the YPA. More specifically, we identified the positions of different stakeholders with respect to the incorporation of child psychological maltreatment into the law, as well as the social representation of the population targeted by the law, first the children, then the parents. The results are discussed in relation to various sociological and historical elements that may deepen our understanding of the implications of these social representations in the debates around child protection.

We found that the same social representation of children as vulnerable and innocent was shared by all the stakeholders involved in the parliamentary hearings studied. This social representation has been mobilized even by stakeholders who defend positions that oppose each other. Our results have thus allowed us to observe the existence of a specific type of social representation, a sub-category of hegemonic representation, the representation that we here call "sacralized" because it has come to be regarded as too important to challenge. The sacralized social representation is characterized by the broad consent with what is regarded as its indisputable veracity. This type of hegemonic social representation can be described as rigid, basic, and symbolically and emotionally charged; above all, it does not allow for alternative representations in society, whether emancipated or polemical. As our results show, the social representation of the vulnerable child, instrumentalized in the stakeholders' discourse to support their positions, did not allow for a free dialogue, thus transforming the sacralized representational object into a taboo object.

We have shown that the social representation of the child achieved the status of a sacralized representation as a result of a specific evolution in a given socio-historical context. Once this status has been achieved, this type of representation has had a limiting impact on a society's ability to discuss sensitive issues such as child abuse. Dialogue has been possible on another register, however. In order to discuss different solutions to the public 
problem of psychological maltreatment of children, the stakeholders who took part in the parliamentary hearings used several social representations of parents in their discourse: dangerous parents, destitute parents, and powerless parents.

On the one hand, these different social representations of parents have allowed for dialogue about child abuse to exist. On the other hand, the hegemonic social representation of dangerous parents has been mobilized in the process of othering individuals and social groups. In our case, we have seen that the image of the poor, young single mother who is addicted to drugs and refuses to get help recurs in the discourse of the stakeholders to illustrate the problem of the psychological maltreatment of children. This representation also serves to protect the identity of the dominant group. The hegemonic social representation of the dangerous parent makes it possible to identify in the already disadvantaged and marginalized groups of society the "culprits" from whom one can differentiate and distinguish oneself as a good parent. The stronger the discourse is in relation to marginalized groups, the less threatened the dominant group feels in relation to the "sacralized" representational object.

Our findings suggest that the concepts of hegemonic representation, and more specifically sacralized representation, may allow us to better understand the process of control of marginalized social groups, particularly young mothers or drug users, that may take place through the child protection system. Further research is needed to better understand the impact that this particular type of sacralized hegemonic representations may have on other representational systems and objects, on the reproduction of power relations [69], and on the ability of our democratic society to freely communicate or not communicate about relevant societal issues.

Author Contributions: Conceptualization, N.P. and L.N.; methodology, N.P.; validation, N.P. and L.N.; formal analysis, N.P.; investigation, N.P.; resources, N.P.; data curation, N.P.; writing-original draft preparation, N.P.; writing-review and editing, N.P. and L.N.; visualization, N.P.; supervision, L.N.; project administration, N.P.; funding acquisition, N.P. Both authors have read and agreed to the published version of the manuscript.

Funding: This research was funded by Fonds De Recherche, Société Et Culture, grant number 209689, and the Ontario Graduate Scholarship Program.

Institutional Review Board Statement: Not applicable.

Informed Consent Statement: Participants consent were waived due to the fact that all the documents analyzed are of a public nature.

Data Availability Statement: All data used in this study can be found in the Quebec National Assembly archives online (see http:/ / www.assnat.qc.ca/fr/travaux-parlementaires/journaux-debats / index-jd/41-1.html, accessed on 15 January 2020).

Acknowledgments: We would like to acknowledge the support of Gefen Bar-On Santor for her editorial feedback.

Conflicts of Interest: The authors declare no conflict of interest. The funders had no role in the design of the study; in the collection, analyses, or interpretation of data; in the writing of the manuscript, or in the decision to publish the results.

\section{Notes}

In this article, the terms psychological ill-treatment and psychological maltreatment are used as synonyms. The term psychological abuse has been avoided in order to include both direct and indirect forms of violence.

2 Excessive control was added to the definition in 2016.

3 In Quebec's democratic institutions, the public hearings that the government may hold on a bill of law shall be designated as parliamentary-committee meetings at which citizens and groups are invited to be heard publicly. The purpose of these hearing is to inform the government and allow citizens, as well as organizations, to express their views on a bill. They also allow political actors and elected members of the Parliament to question and discuss the subject under consideration with them. Most importantly, these hearings allow the Minister introducing a bill to discuss the various issues raised by their bill directly with the 
stakeholders who may be affected by it. In the case of this study, Margaret F. Delisle, the delegated minister for Youth Protection and Rehabilitation from 2005 to 2007 under the Liberal government, sponsored the bill.

4 The case of the Duplessis' orphans refers to the sad fate of thousands of orphans falsely declared to be mentally ill by the Quebec government in the 1940s and 1950s in order to obtain federal grants. These children were abused, even murdered, in hospices and orphanages run by the Catholic Church, which was aware of the fraudulent scheme. The name given to them refers to the Quebec premier of the time, Maurice Duplessis.

5 The names of stakeholders are provided in English even when formal English translations were not available (we did the translation ourselves).

6 All quotes by stakeholders have been translated from French into English by the authors.

7 The notion of re-victimization of women generally refers to the fact that a woman who has already been violated can be victimized again by the State's various legal systems and their procedures, such as through cross-examination in court or youth protection inquiries. The phenomenon has been the subject of many studies. See [24] for an excellent review of the situation in Quebec.

\section{References}

1. Joyal, R. Entre Surveillance et Compassion: L'évolution des la Protection de L'enfance au Québec; Presses de l'Université du Québec: Québec, QC, Canada, 2000.

2. Provost, M. Le mauvais traitement de l'enfant: Perspectives historiques et comparatives de la législation sur la protection de la jeunesse. Rev. De Droit De L'université De Sherbrooke 1991, 22, 5-62. [CrossRef]

3. Drapeau, S.; Hélie, S.; Turcotte, D.; Chateauneuf, D.; Poirier, M.-A.; Saint-Jacques, M.-C.; Turcotte, G. L'évaluation des Impacts de la Loi sur la Protection de la Jeunesse: Qu'en Est-il Huit ans Plus Tard? Final Report Submitted to the Direction des Jeunes et des Familles du MSSS, Québec, Centre de Recherche sur l'adaptation des Jeunes et des Familles à Risque; 2015; 76p. Available online: http:/ / www.cms.fss.ulaval.ca/recherche/upload/jefar/fichiers/rapport_complet_elpj_2015.pdf (accessed on 12 March 2017).

4. Youth Protection Act. RLRQ, c. P-34.1. Available online: http://legisquebec.gouv.qc.ca/en/showversion/cs/P-34.1?code=se: 38\&pointInTime=20210625\#20210625 (accessed on 12 August 2021).

5. Baker, A.J.L.; Brassard, M.R.; Rosenzweig, J. Psychological maltreatment: Definition and reporting barriers among American professionals in the field of child abuse. Child Abus. Negl. 2021, 114, 104941. [CrossRef]

6. Brassard, M.R.; Hart, S.N.; Glaser, D. Psychological maltreatment: An international challenge to children's safety and well being. Child Abus. Negl. 2020, 110, 104611. [CrossRef]

7. Godbout, É.; Saini, M.; Turbide, C. Les Conflits Sévères De Séparation: Le Point De Vue Et Les Besoins Des Intervenants En Protection De La Jeunesse. Rev. Québécoise De Psychol. 2019, 39, 99-124. [CrossRef]

8. Malo, C.; Hélie, S.; Lavergne, C. Psychological Maltreatment: The Response of Quebec Child Protection Services. Child Welf. 2019, 97, 45-60.

9. Chamberland, C.; Fallon, B.; Black, T.; Trocme, N. Emotional maltreatment in Canada: Prevalence, reporting and child welfare responses (CIS2). Child Abus. Negl. 2011, 35, 841-854. [CrossRef] [PubMed]

10. Trocmé, N.; Kyte, A.; Sinha, V.; Fallon, B. Urgent Protection versus Chronic Need: Clarifying the Dual Mandate of Child Welfare Services across Canada. Soc. Sci. 2014, 3, 483-498. [CrossRef]

11. Glaser, D. Emotional abuse and neglect (psychological maltreatment): A conceptual framework. Child Abus. Negl. 2002, 26, 697-714. [CrossRef]

12. English, D.; Thompson, R.; White, C.R.; Wilson, D. Why should child welfare pay more attention to emotional maltreatment? Child. Youth Serv. Rev. 2015, 50, 53-63. [CrossRef]

13. Fleury-Steiner, R.E.; Miller, S.L.; Maloney, S.; Bonistall Postel, E. "No Contact, Except": Visitation Decisions in Protection Orders for Intimate Partner Abuse. Fem. Criminol. 2016, 11, 3-22. [CrossRef]

14. Lapierre, S.; Côté, I. On n'est pas là pour régler le problème de violence conjugale, on est là pour protéger l'enfant: La conceptualisation des situations de violence conjugale dans un centre jeunesse du Québec. Serv. Soc. 2011, 57, 31-48. [CrossRef]

15. Glaser, D.; Prior, V. Is the Term Child Protection Applicable to Emotional Abuse? Child Abus. Rev. 1997, 6, 315-329. [CrossRef]

16. Malo, C.; Moreau, J.; Lavergne, C.; Hélie, S. Psychological Maltreatment, the Under-Recognized Violence Against Children: A new Portrait from Quebec. Child Welf. 2016, 95, 77-99.

17. Morelen, D.; Shaffer, A. Understanding Clinical, Legal and Ethical Issues in Child Emotional Maltreatment. J. Agression Maltreatment Trauma 2012, 21, 188-201. [CrossRef]

18. Habermas, J. Between Facts and Norms; Contributions to a Discourse Theory of Law and Democracy; MIT Press: Cambridge, MA, USA, 1998.

19. Blumer, H. Social Problems as Collective Behavior. Soc. Probl. 1971, 18, 298-306. Available online: http://www.jstor.org/stable/ 799797 (accessed on 12 September 2016). [CrossRef]

20. Lancaster, K.; Ritter, A. Examining the construction and representation of drugs as a policy problem in Australia's National Drug Strategy documents 1985-2010. Int. J. Drug Policy 2014, 25, 81-87. [CrossRef] [PubMed]

21. Burlone, N. Le sens de la famille: Réflexion autour du choix des instruments de politique familiale. Économie Et Solidar. 2007, 38, 105-121. 
22. Burlone, N.; Couture, J.-P. Gouvernance et choix des instruments de politique familiale: De la logique des systèmes au monde vécu. In L'État et la Société Civile Sous le Joug de la Gouvernance; Rouillard, C., Burlone, N., Eds.; Presses de 1'Université Laval: Quebec City, QC, Canada, 2011; pp. 91-110.

23. Fairclough, I.; Fairclough, N. Political Discourse Analysis, A Method for Advanced Students; Taylor and Francis Group: New York, NY, USA; Routledge: London, UK, 2012.

24. Moscovici, S. La Psychanalyse: Son Image et son Public: Étude sur la Représentation Sociale de la Psychanalyse; Presses Universitaires de France: Paris, France, 1961.

25. Giddens, A. The Constitution of Society; Polity Press: Cambridge, UK, 1984.

26. Moscovici, S. The phenomenon of social representations. In Social Representations; Farr, R.M., Moscovici, S., Eds.; Cambridge and Editions de la Maison des Sciences de l'Homme: Paris, France; Cambridge University Press: Cambridge, UK, $1984 ;$ pp. 3-69.

27. Abric, J.-C. Pratiques Sociales et Représentations; Presses Universitaires de France: Paris, France, 1994.

28. Negura, L.; Lavoie, C. La pensée sociale et professionnelle dans l'action: l'intervention au carrefour des représentations. In L'Intervention En Sciences Humaines: L'importance Des Représentations; Negura, L., Ed.; Presses de l'Université Laval: Québec, QC, Canada, 2016; pp. 11-40.

29. Negura, L.; Plante, N. The Construction of Social Reality as a Process of Representational Naturalization. The Case of the Social Representation of Drugs. JTSB 2021, 51, 124-144.

30. Moscovici, S. Notes toward a description of Social Representations. Eur. J. Soc. Psychol. 1988, 18, 211-250. [CrossRef]

31. Turmel, A. Le Québec par ses Enfants; Une Sociologie Historique (1850-1950); Les Presses de l'Université de Montréal: Montréal, QC, Canada, 2017.

32. Kempe, C.H.; Silverman, F.N.; Steele, B.F.; Droegemueller, W.; Silver, H.K. The Battered-Child Syndrome. JAMA 1962, 181, 17-24. [CrossRef]

33. Hacking, I. The Social Construction of What? Harvard University Press: Cambridge, MA, USA, 1999.

34. Gelles, R.J. The Social Construction of Child Abuse. Am. J. Orthopsychiatry 1975, 45, 363-371. [CrossRef] [PubMed]

35. Moscovici, S. Why a Theory of Social Representations? In Representations of the Social; Deaux, K., Philogène, G., Eds.; Blackwell Publishers: Malden, MA, USA, 2001; pp. 8-35.

36. Gillespie, A. Social representations, alternative representations and semantic barriers. JTSB 2008, 38, 375-391. [CrossRef]

37. Höijer, B. Social Representations Theory; A New Theory for Media Research. Nord. Rev. 2011, 2, 3-16. [CrossRef]

38. de la Sablonnière, É.; Fortin, A. Violence conjugale et qualité de la relation mère-enfant: Effet médiateur ou modérateur de la santé des mères? Can. J. Behav. Sci. 2010, 42, 212-221. [CrossRef]

39. Lapierre, S. Are Abused Women Neglectful mothers? A Critical Reflection Based on Women's Experiences. In Gender and Child Welfare Society; Featherstone, B., Hooper, C.-A., Scourfield, J., Taylor, J., Eds.; John Wiley \& Sons: Hoboken, NJ, USA, 2010; pp. 121-148.

40. Chamberland, C. Violence Parentale et Violence Conjugale; Des Réalités Plurielles, Multidimensionnelles et Interreliées; Presses de l’Université du Québec: Québec, QC, Canada, 2003.

41. Chamberland, C.; Léveillé, S.; Trocme, N. Enfants à Protéger, Parents à Aider; Des Univers à Rapprocher; Presses de l’Université du Québec: Québec, QC, Canada, 2007.

42. Lessard, G.; Alvarez-Lizotte, P. The exposure of children to intimate partner violence: Potential bridges between two fields in research and psychosocial intervention. Child Abus. Negl. 2015, 48, 29-38. [CrossRef] [PubMed]

43. Paillé, P.; Mucchielli, A. L'analyse Qualitative en Sciences Humaines et Sociales, 2nd ed.; Armand Colin: Paris, France, 2008.

44. Musto, D.F. The American Disease: Origins of Narcotic Control, 3rd ed.; Oxford University Press: New York, NY, USA, 1999.

45. Seddon, T. Inventing Drugs: A Genealogy of a Regulatory Concept. J. Law Soc. 2016, 43, 393-415. [CrossRef]

46. Cliche, M.-A. Morale chrétienne et double standard: Les filles-mères à l'hôpital de la Miséricorde à Québec 1874-1972. Hist. Soc. 1991, 24, 85-125.

47. Bouffard, M. L'institutionnalisation de L'enfance de la Marge; Le cas de L'école D'industrie de L'hospice St-Joseph-de-laDélivrance. Master's Thesis, Laval University, Québec, QC, Canada, 2011.

48. Lacasse, A.-A. L'institutionnalisation de L'enfance Déviante: Le cas de l'Hospice Saint-Charles (1870-1950). Master's Thesis, Laval University, Québec, QC, Canada, 2010.

49. Markova, I. Dialogicité et Représentations Sociales; Presses Universitaires de France: Paris, France, 2007.

50. Marková, I. The Dialogical Mind: Common Sense and Ethics; Cambridge University Press: Cambridge, UK, 2016. [CrossRef]

51. Cook, D.T. “Pricing The Priceless Child”: A Wonderful Problematic. J. Hist. Child. Youth 2012, 5, 468-473. [CrossRef]

52. Labbé, J. La Maltraitance des Enfants en Occident: Une Histoire D’hier à Aujourd'hui; Presses de l'Université Laval: Québec, QC, Canada, 2019.

53. Zelizer, V.A. Pricing the Priceless Child: The Changing Social Value of Children; Basic Books: New York, NY, USA, 1985.

54. Thorne, B. "Pricing the Priceless Child" as a Teaching Treasure. J. Hist. Child. Youth 2012, 5, 474-480. [CrossRef]

55. Segalen, M.; Martial, A. Sociologie de la Famille, 8th ed.; Arman Colin: Paris, France, 2013.

56. Zelizer, V.A. The Priceless Child Turns Twenty-seven. J. Hist. Child. Youth 2012, 5, 449-456. [CrossRef]

57. Sabri, O.; Manceau, D.; Pras, B. Le tabou, un concept peu exploré en marketing. Rech. Et Appl. En Mark. 2010, 25, 59-86. [CrossRef]

58. Moscovici, S. Social representations and pragmatic communication. Soc. Sci. Inf. 1994, 33, 163-177. [CrossRef]

59. Hacking, I. The Making and Molding of Child Abuse. Crit. Inq. 1991, 17, 253-288. [CrossRef] 
60. Healy, K. Social Work Theory in Context; Creating Frameworks for Practice, 2nd ed.; Palgrave Macmillan: London, UK, 2014.

61. Joffe, H. Risk and 'the Other'; Cambridge University Press: Cambridge, MA, USA, 1999.

62. Québec, G. Instaurer une Société Bienveillante Pour nos Enfants et nos Jeunes; Rapport de la Commission Spéciale sur les Droits des Enfants et la Protection de la Jeunesse; Gouvernement du Québec: Québec, QC, Canada, 2021. Available online: https://www.csdepj.gouv. qc.ca/fileadmin/Fichiers_clients / Rapport_final_3_mai_2021/2021_CSDEPJ_Rapport_version_finale_numerique.pdf (accessed on 4 May 2021).

63. Davie, N. Corps et délinquance juvénile en Angleterre dans les années 1830-1865: Le milieu remis en question. Rev. D’histoire De L'enfance Irrégulière 2006, 8, 49-62. [CrossRef]

64. Strimelle, V. La gestion de la déviance des filles à Montréal au XIXe siècle. Les institutions du Bon-Pasteur d'Angers (1869-1912). Rev. De L'histoire De L'enfance Irrégulière 2003, 5, 61-83. [CrossRef]

65. Bourdieu, P. Sur le pouvoir symbolique. Annales 1977, 32, 405-411. [CrossRef]

66. Humphreys, C.; Absler, D. History repeating: Child protection responses to domestic violence. Child Fam. Soc. Work. 2011, 16, 464-473. [CrossRef]

67. Bernheim, E.; Lebeke, C. De la mère «normale»: Normes, expertises et justice en protection de la jeunesse. Enfances Fam. Générations 2014, 20, 109-127. Available online: http:/ / efg.revues.org/532 (accessed on 15 May 2021). [CrossRef]

68. Scourfield, J.; Coffey, A. Understanding Gendered Practice in Child Protection. Qual. Soc. Work 2002, 1, 319-340. [CrossRef]

69. Negura, L.; Plante, N.; Lévesque, M. The role of social representations in the construction of power relations. JTSB 2020, 50, 25-41. [CrossRef] 